RASĀYAN J. Chem.

Vol. 12 | No. 4 |2290 - 2295| October - December | 2019 ISSN: 0974-1496 | e-ISSN: 0976-0083 | CODEN: RJCABP

RJC http://www.rasayanjournal.com http://www.rasayanjournal.co.in

\title{
REDUCTION OF STRENGTH OF DOMESTIC WASTEWATER USING NATURAL FIBROUS MATERIALS
}

\author{
P. Vijayalakshmi*, Eshanthini P., Vanitha S., R. Sharath Kumar \\ and $B$. Vigneshwaran \\ Department of Civil Engineering, Sathyabama Institute of Science and Technology, \\ Chennai-600119, (Tamil Nadu) India \\ *E-mail: vijayalakshmipanneerselvam@yahoo.co.in
}

\begin{abstract}
The natural fibrous materials which are effective in purification purpose has been identified and used for domestic purification. The materials used as a filter bed in this study are Sisal fiber, Areca husk fiber activated carbon and river sand. The removal efficiency of these materials has been studied by setting the filter bed for different contact period. Influent greywater sample (raw water) and effluent greywater smaple (treated water) collected and analyzed for $\mathrm{pH}, \mathrm{TDS}, \mathrm{TSS}, \mathrm{TH}, \mathrm{BOD}, \mathrm{COD}$, oil and grease, chloride and sulphate in the laboratory and compared with THPCB and WHO standards. The removal efficiency of this parameter is between 0 to 25 are $12.5 \%$ (TDS), between 30 to 40 are 50\% (TH, BOD, COD, sulphate) and 40 to 50 are 25\% (TSS, oil and grease) and above 50 are $12.5 \%$ (Chloride).
\end{abstract}

Keywords: Grey Water, Purification, Fibrous Material, Agave Sisalana, Areca Nut Husk.

(C) RASĀYAN. All rights reserved

\section{INTRODUCTION}

The increasing disparity between readily available sources of clean water and the growing demand associated with population growth and economic development witnessed in recent decades. In the overall water resources budget, a sustainable water management strategy requires that decision-makers recognize treated wastewater as a vital asset instead of a waste medium for costly disposal which increases the attention given to the greywater utilization. Decentralized wastewater treatment or treating wastewater at source is gaining importance as the country is facing water shortage for meeting various water uses. ${ }^{1}$ India supports over $15 \%$ of the world's population with only $4 \%$ of the world's water resources by occupying only 3.29 million $\mathrm{km}^{2}$ geographical areas which form $2.4 \%$ of the world's land area. ${ }^{2}$

Sand filtration is a primary stage of treatment for the reuse of greywater. ${ }^{3}$ The domestic wastewater generated from the shower, washbasin and a laundry purpose is greywater. Well-known benefits on potable water savings are the reuse of grey-water, however, the significant knowledge gap exists on their appropriate treatment and supply to end-user in a cost-effective way. ${ }^{4}$ The rural domestic sewages can be segregated into greywater $(\mathrm{GW})$ that is the wastewater generated from washing basin, bathroom, kitchen, laundry and black-water is mainly from toilet and farm life stock water and black-water (BW). ${ }^{5}$ Due to the high space requirement and technological of greywater treatment, full greywater treatment and reuse are rarely feasible at the household level. ${ }^{6}$ Sugarcane bagasse has been used as an alternative adsorbent for the removal of color as it is cheap and abundantly available in India. ${ }^{11}$ Natural coagulants have a bright future, because of their abundant source, low price, environment-friendly, multi-functionality and their biodegradable nature in water purification. ${ }^{12}$

Knowing the increased demand for groundwater in urban areas and cities, the water should be recycled or treated before releasing to natural water sources such as rivers or lakes or in open land as groundwater recharge. Considering this the domestic wastewater has been treated in small scale which is more or less effective and can be re-used for various purposes such as lawn irrigation, flushing of toilets etc., In this study, Sisal fiber (Agave Sisalana family) and Areca Huskbelongs to the species areca catechu L., under

Rasayan J. Chem., 12(4), 2290-2295(2019)

http://dx.doi.org/10.31788/RJC.2019.1245453




RASĀYAN J. Chem.

Vol. 12 | No. 4 |2290 - 2295| October - December | 2019

the family palmacea are used to treat greywater due its high cellulose content which is good at filtration and are easily bio-degradable.

\section{EXPERIMENTAL}

The present work is intended to study the application of the comparative study between the Areca fibre and Agavasisalana for treating domestic wastewater and to know the comparative removal efficiency of $\mathrm{pH}$, TDS, TSS, Total hardness, BOD, COD, Oil \& grease, Chloride, sulphate, with river sand and activated carbon bed in a small volume reactor.

\section{Collection and Preparation of Materials}

Agave Sisalana plant Fibre and Areca Nut or Beetle Nut husk, river sand and activated carbon are used for the experimental study. The fiber has been extracted from the leaves of the Agave Sisalana plant and dried in open sunlight and the fiber is soaked in clean distilled for about 24 hours which makes the fiber usable and also for the removal of natural color. Areca Nut or Beetle Nut husk soaked in clean distilled for about 24 hours to loosen the husk and to be easy to grind to make as fiber and dried in open sunlight. River sand collected and cleaned with clear distilled water until the dust and clay particles are removed from the sand and dried in sunlight than with a sieve size of $2.5 \mathrm{~mm}$. And to remove the color activated carbon is used. A greywater sample collected from the house everyday evening 6-7 pm for 10 days.



Fig.-1: Sisal Fibre and Areca Nut Husk (before and after grinding), Sand, Activated carbon

\section{Experimental Set-up}

In this study, a laboratory-scale experimental set-up was used (Fig.-1). The set-up is made with glass materials of thickness $10 \mathrm{~mm}$ and the length, breadth and depth are $15 \mathrm{~cm}, 15 \mathrm{~cm}$ and $75 \mathrm{~cm}$ respectively.

\section{RESULTS AND DISCUSSION}

In the experimental set-up, one kilogram of Sisal fiber and Areca Nut husk fiber-filled to the depth of 30 $\mathrm{cm}$ and 2 kilograms of river sand to the depth of $10 \mathrm{~cm}$ and 250 grams of activated carbon used. To collect the influent water (raw grey water) from the typical single household, the PVC pipes are used and to maintain the HLR conditions, the adjustable valve was used, by gravity the influent water was flowing through the multi-layered filter bed with contact time and collected and analyzed in the laboratory. Effluent water (treated greywater) collected day one, fifth and tenth day.

Influent and effluent water collected are analyzed by Table-1 shows the details of the concentration of the parameters before and after the treatment of greywater. The removal efficiency was calculated as the percentage removal for each parameter: $R=\left(1-C_{e} / C_{i}\right) 9100 \%$, where the average effluent $\left(C_{e}\right)$ and influent $\left(\mathrm{C}_{\mathrm{i}}\right)$ concentrations in $\mathrm{mg} / \mathrm{L}$, respectively (except $\mathrm{pH}$ ). The variations in the concentration of individual parameters are shown in Fig.-4 and 5. 
RASĀYAN J. Chem.

Vol. 12 | No. 4 |2290 - 2295| October - December | 2019

Table -1:Concentration Details of Influent (Raw Grey Water) and Effluent (Treated Grey Water) and Removal Efficiency in Percentage

\begin{tabular}{|c|c|c|c|c|c|c|c|c|}
\hline \multirow[b]{2}{*}{ Parameters } & \multirow{2}{*}{$\begin{array}{c}\text { *Influent } \\
\text { (raw } \\
\text { greywater) } \\
C_{\mathrm{i}}\end{array}$} & \multicolumn{5}{|c|}{ *Effluent (treated greywater } & \multirow{2}{*}{$\begin{array}{c}\text { TNPCB } \\
\text { Tolerance } \\
\text { Limit for } \\
\text { Effluent water }\end{array}$} & \multirow[b]{2}{*}{$\begin{array}{c}\text { WHO } \\
\text { standards }\end{array}$} \\
\hline & & Day 1 & Day 5 & Day 10 & $\begin{array}{c}\text { Average } \\
\mathrm{C}_{\mathrm{e}}\end{array}$ & \begin{tabular}{|c|} 
Removal \\
Efficiency (\%) \\
R
\end{tabular} & & \\
\hline $\mathrm{pH}$ & 7.51 & 7.45 & 7.43 & 7.41 & 7.43 & 1.07 & $6.5-9$ & $5-9$ \\
\hline TDS & 1246 & 1109 & 954 & 755 & 939.33 & 24.61 & 2100 & - \\
\hline TSS & 115 & 104 & 62 & 21 & 62.33 & 45.8 & 50 & 35 \\
\hline Total hardness & 1395 & 1104 & 900 & 654 & 886 & 36.49 & - & - \\
\hline BOD & 21 & 19 & 13 & 7 & 13 & 38.1 & 20 & 40 \\
\hline COD & 193 & 177 & 141 & 65 & 127.67 & 33.85 & 250 & 120 \\
\hline Oil and grease & 8.9 & 7.5 & 5.6 & 1 & 4.7 & 47.19 & 10 & 10 \\
\hline Chloride & 2714 & 2011 & 1356 & 441 & 1269.33 & 53.23 & 1000 & 750 \\
\hline Sulphate & 354 & 309 & 298 & 109 & 238.67 & 32.58 & 1000 & 750 \\
\hline
\end{tabular}

* Unit is in $\mathrm{mg} / \mathrm{l}$

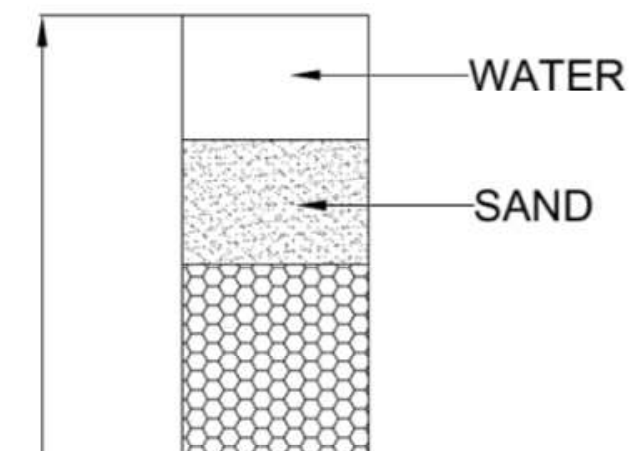

$75 \mathrm{CM}$

ARECA NUT HUSK \& AGAVE SISALANA FIBRE

$\stackrel{15 \longrightarrow}{\longleftrightarrow}$

Fig.-2: Details of Experimental Set-Up

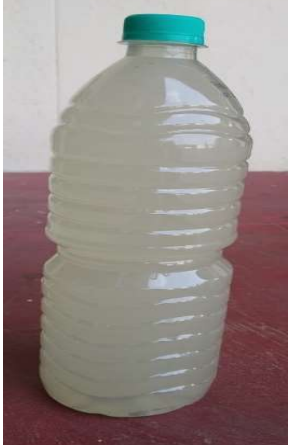

Fig.-3: Raw Water Sample (Raw Greywater) 
RASĀYAN J. Chem.

Vol. 12 | No. 4 |2290 - 2295| October - December | 2019

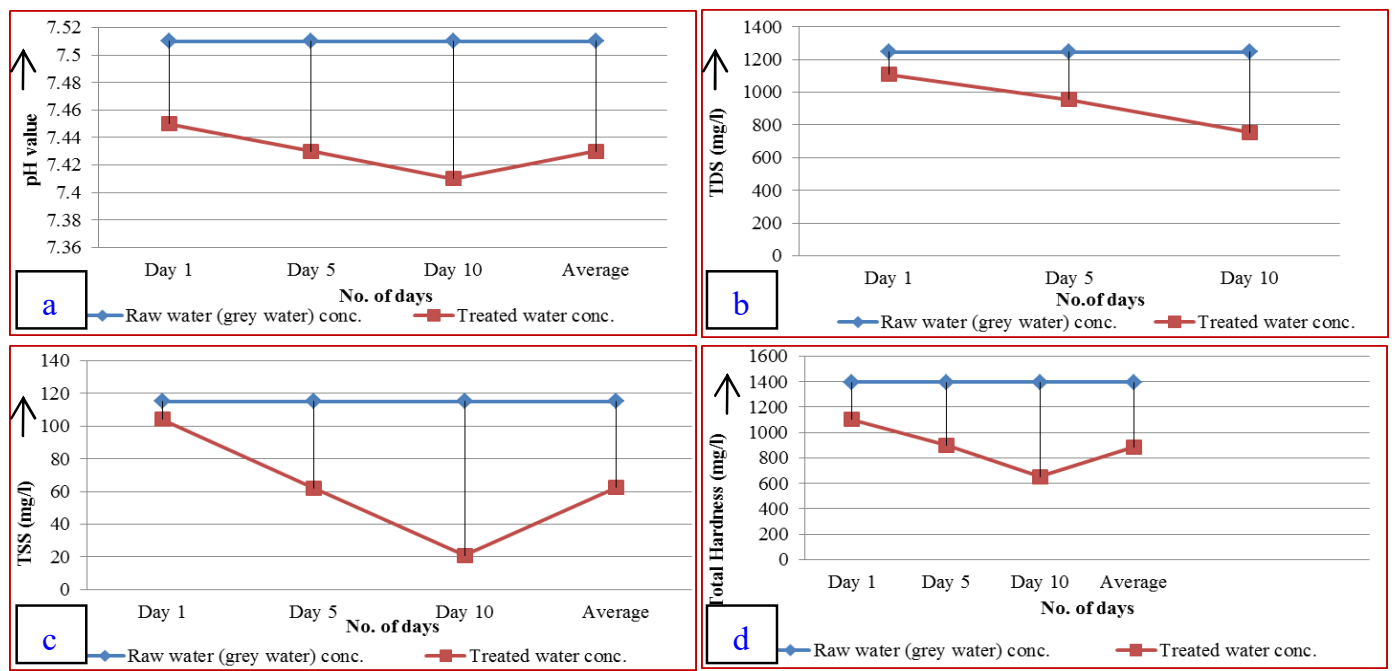

Fig.-4: Variation in Concentration (pH value, TDS, TSS \& Total Hardness)

pH

$\mathrm{pH}$ value gradually decreasing compared with influent grey water (7.51)and the value of first, fifth and tenth day are $7.45,7.43$ and 7.41 respectively. And the average $\mathrm{pH}$ value is 7.43 which is just above the neutral value 7.0 and within the THPCB tolerance limit for effluent water $(6.5-9.0)$ and WHO standards $(5.0-9.0)$. The effluent grey water removal efficiency is $1.07 \%$ which shows the effluent greywater is alkaline. Figure-4(a) shows the variation in $\mathrm{pH}$ value. Even though $\mathrm{pH}$ has no direct effect on human health, it shows close relations with some other chemical constituents of water. ${ }^{7}$

\section{TDS}

TDS value gradually decreasing compared with influent greywater $(1246 \mathrm{mg} / /)$ and the value of first, fifth and tenth day are $1109 \mathrm{mg} / 1,954 \mathrm{mg} / 1 \& 755 \mathrm{mg} / 1$ respectively. And the average TDS value is $939.33 \mathrm{mg} / 1$ and within the THPCB tolerance limit for effluent water $(2100 \mathrm{mg} / \mathrm{l})$. The effluent grey water removal efficiency is $24.61 \%$ which shows the effluent greywater is alkaline. Figure 4 (b) shows the variation of TDS value.

TSS

TSS value gradually decreasing compared with influent grey water $(115 \mathrm{mg} / \mathrm{l})$ and the value of first, the fifth and tenth day is $104 \mathrm{mg} / 1,62 \mathrm{mg} / 1$ \& $21 \mathrm{mg} / 1$ respectively. And the average TSS value is $62.33 \mathrm{mg} / 1$ and above the THPCB tolerance limits for effluent water $(50 \mathrm{mg} / \mathrm{l})$ and WHO standards $(35 \mathrm{mg} / \mathrm{l})$. The effluent grey water removal efficiency is $45.87 \%$. Figure-4(c) shows the variation of TSS value. The removal of a fraction of suspended particles plays a vital role in the efficient functioning of the main treatment scheme. And for removing the suspended particles (dust, hair and food particles escaping kitchen sink strainer), fine screens of size less than $6 \mathrm{~mm}$ can be used. ${ }^{1}$

\section{Total Hardness (TH)}

TH value gradually decreasing compared with influent grey water $(1395 \mathrm{mg} / \mathrm{l})$ and the value of first, the fifth and tenth day is $1104 \mathrm{mg} / 1,900 \mathrm{mg} / \mathrm{l}$ and $654 \mathrm{mg} / \mathrm{l}$ respectively. And the average TH concentration is $886 \mathrm{mg} / 1$ and above the THPCB tolerance limits for effluent water and WHO standards. The effluent grey water removal efficiency is $36.49 \%$. Figure 4 (d) shows the variation of total hardness.

\section{BOD}

BOD value gradually decreasing compared with influent grey water $(21 \mathrm{mg} / \mathrm{l})$ and the value of first, the fifth and tenth day is $19 \mathrm{mg} / 1,13 \mathrm{mg} / \mathrm{l}$ and $7 \mathrm{mg} / 1$ respectively. And the average BOD concentration is 13 $\mathrm{mg} / \mathrm{l}$ and within the THPCB tolerance limits for effluent water $(20 \mathrm{mg} / \mathrm{l})$ and WHO standards $(40 \mathrm{mg} / \mathrm{l})$. The effluent grey water removal efficiency is $38 \%$. Figure-5(a) shows the variation of BOD value. The 
RASĀYAN J. Chem.

Vol. 12 | No. 4 |2290 - 2295| October - December | 2019

removal efficiency of BOD by using Agava as filter media was found to be $56.2 \%$ for $15 \mathrm{~cm}$ depth which was higher than that of Areca which was found to be $52.08 \%{ }^{8}$

\section{COD}

COD value gradually decreasing compared with influent grey water $(193 \mathrm{mg} / \mathrm{l})$ and the value of first, the fifth and tenth day is $177 \mathrm{mg} / 1,141 \mathrm{mg} / 1$ \& $65 \mathrm{mg} / 1$ respectively. And the average COD concentration is $127.67 \mathrm{mg} / \mathrm{l}$ and within the THPCB tolerance limits for effluent water $(250 \mathrm{mg} / \mathrm{l})$ and WHO standards $(120 \mathrm{mg} / \mathrm{l})$. The effluent grey water removal efficiency is $33.85 \%$. Figure-5(b) shows the variation of COD value. The removal efficiency of COD by using Agava as filter media was found to be $56 \%$ for $15 \mathrm{~cm}$ depth which was higher than that of Areca which was found to be $52 \%{ }^{8}$ Friedler ${ }^{9}$ recommends excluding fixtures (kitchen sink and dishwasher) from a greywater system because they constitute only $25-30 \%$ of greywater volume but contribute nearly half of its COD content.

\section{Oil and Grease}

Oil and grease value gradually decreasing compared with influent grey water $(8.9 \mathrm{mg} / \mathrm{l})$ and the value of first, fifth and tenth day is $7.5 \mathrm{mg} / 1,5.6 \mathrm{mg} / 1$ and $1 \mathrm{mg} / 1$ respectively. And the average oil and grease value is $4.7 \mathrm{mg} / 1$ and within the THPCB tolerance limits for effluent water $(10 \mathrm{mg} / \mathrm{l})$ and WHO standards $(10 \mathrm{mg} / \mathrm{l})$. The effluent grey water removal efficiency is $33.85 \%$. Figure-5(c) shows the variation of oil and grease value. Because of less soluble in water which reduces their microbial degradation ${ }^{10}$ thereby affecting the treatment units and hence oil trappers must be provided after screens to remove oil and grease.


Fig.-5: Variation in Concentration (BOD, COD, Oil and grease, Chloride\&Sulphate)

\section{Chloride}

Chloride value gradually decreasing compared with influent greywater $(2714 \mathrm{mg} / 1)$ and the value of first, fifth and tenth day are $2011 \mathrm{mg} / 1,1356 \mathrm{mg} / 1$ and $441 \mathrm{mg} / 1$ respectively. And the Chloride concentration is $1269.33 \mathrm{mg} / \mathrm{l}$ and above the THPCB tolerance limits for effluent water $(1000 \mathrm{mg} / \mathrm{l})$ and within WHO standards $(750 \mathrm{mg} / 1)$. The effluent grey water removal efficiency is $53.23 \%$. Figure-5(d) shows the variation of chloride value 
RASĀYAN J. Chem.

Vol. 12 | No. 4 |2290 - 2295| October - December | 2019

\section{Sulphate}

Sulphate value gradually decreasing compared with influent grey water $(354 \mathrm{mg} / \mathrm{l})$ and the value of first, fifth and tenth day is $309 \mathrm{mg} / \mathrm{l}, 298 \mathrm{mg} / \mathrm{l}$ and $109 \mathrm{mg} / \mathrm{l}$ respectively. And the average Sulphate concentration is $238.67 \mathrm{mg} / \mathrm{l}$ and within the THPCB tolerance limits for effluent water $(1000 \mathrm{mg} / \mathrm{l})$ and WHO standards $(750 \mathrm{mg} / 1)$. The effluent grey water removal efficiency is $32.58 \%$. Figure-5(e) shows the variation of sulphate value.

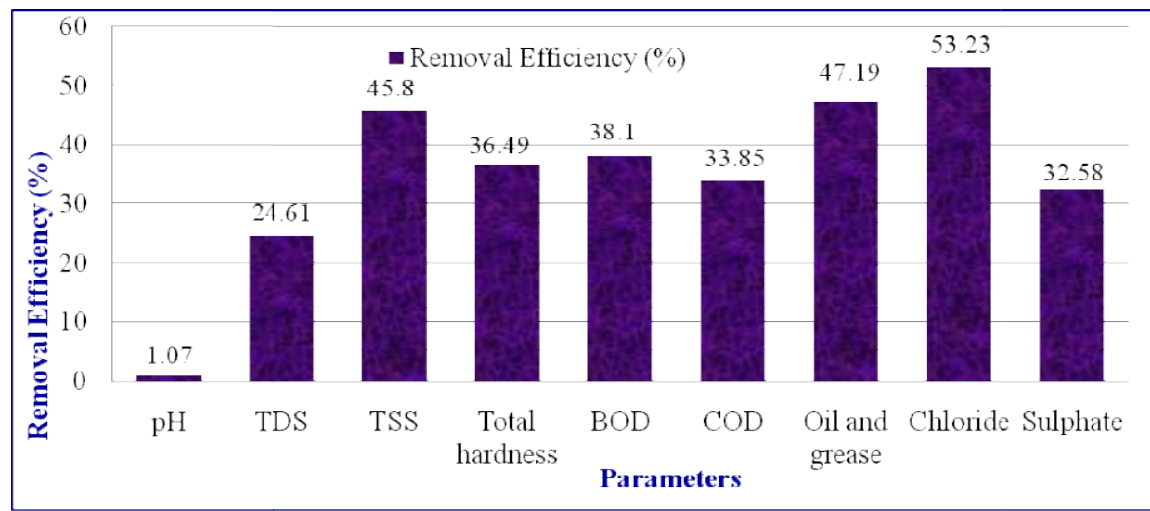

Fig.-6: Variation in Removal Efficiency (expect pH)

\section{CONCLUSION}

Figure-6 shows the variation in removal efficiency. Influent greywater sample (raw water) and effluent greywater water sample (treated water) collected and tested for $\mathrm{pH}$, TDS, TSS, TH, BOD,COD,oil and grease, chloride and sulphate in the laboratory and compared with THPCB and WHO standards. And the $\mathrm{pH}$ value of influent greywater is 7.51 and effluent greywater is 7.43 i.e., $1.07 \%$ decreases the value. The removal efficiency of TDS and chloride are within and above $25 \%(24.61 \%)$ and $50 \%(53.23 \%)$ respectively. Total hardness, BOD, COD and sulphate are between $30 \%$ to $40 \%$. The removal efficiency of TSS and oil and grease is $40 \%$ to $50 \%$. Expect total suspended solids, total hardness and chloride, all the parameters tested are within the limits as compared with THPCB and WHO standards. This present study concludes that the treated greywater can be used for non-potable uses (lawn irrigation, re-flushing of toilets etc.), safe to release into open environment and to nearby water sources such as a lake, river etc., and also it can be recharged into groundwater.

\section{REFERENCES}

1. Karnapa Ajit, International Research Journal of Engineering and Technology, 3(5), 2665(2016).

2. J.S. Lambe and R.S. Chougule, Journal of Mechanical and Civil Engineering, 20.

3. Marcin Spychala, Jakub Nie'c, Pawel Zawad zk, Appl. Sci., (9), 770(2019), DOI: $10.3390 /$ app 9040770

4. M. Mohamed and Rezaul K. Chowdhury, Int. J. Waste Resour., 6(3), DOI:10.4172/22525211.C1.003.

5. M. Halalsheh, S. Dalahmeh, M. Sayed, W. Suleiman, M. Shareef, M. Mansour, M. Safi, Bioresour. Technol., 99(14), 6635(2008), DOI: 10.1016/j.biortech.2007.12.029. Epub 2008 Mar 4.

6. Rafat Khalaphallah, Chemical and Process Engineering. Ecole des Mines de Nantes, 2012. English.

7. R. Pitt, S. Clark, and R. Field, Urban Water, 1, 217(1999).

8. Munigalasri Kavya, Pingili Vydehi and Bollaboina Laxmi, International Research Journal of Engineering and Technology, 5(5), 3539(2018)

9. E. Friedler, Environmental Technology, 25, 997(2004), DOI: 10.1080/09593330.2004.9619393

10. Waste Water Engineering: Treatment and Reuse, Metcalf and Eddy, Fourth Edition.

11. Mahalakshmi, Mathivanan and S.E. Saranaathan, Rasayan J. Chem., 11(2), 877(2018), DOI: 10.31788/RJC.2018.1122086

12. S. Ramesh, J. S. Sudarsan and M. Jothilingam, Rasayan J. Chem., 9(3), 325(2016)

[RJC-5453/2019] 